\title{
TEAM WORK IN THE TRAINING OF A SAFETY TECHNICIAN
}

\author{
Vladimír SOTÁK - Mária MUCHOVÁ - Miroslav ŠEBO - Robert SOTÁK
}

\begin{abstract}
Authors point at the wide spectrum and variety of knowledge that a future safety technician should gain in the course of his studies. Practice requires such safety technician who is skilled in the area of integrated systems, information technologies and foreign languages ( especially English language). To reach this range of knowledge, cooperation between teachers who create the content of curriculum and teaching materials is needed.
\end{abstract}

Key words: theoretical knowledge, ICT, know-how for applications, language skills, practical experience

\section{TÍMOVÁ PRÁCA V PRÍPRAVE BEZPEČNOSTNÉHO TECHNIKA}

Resumé: Autori v príspevku poukazujú na široké spektrum a rôznorodost' poznatkov, ktoré by mal budúci bezpečnostný technik pri štúdiu získat'. Prax požaduje bezpečnostného technika vybaveného o.i. poznatkami z oblasti integrovaných systémov, informačných technológií a cudzích jazykov, kde dominuje najmä požiadavka na komunikáciu $\mathrm{v}$ anglickom jazyku. Jedným $\mathrm{z}$ riešení pre naplnenie týchto požiadaviek je tímová spolupráca učitel’ov pri zostavovaní učebných materiálov i pri výučbe.

Klíčová slova: teoretické poznatky, IKT, know-how pre aplikácie, jazykové kompetencia, praktické skúsenosti

\section{Introduction}

The term Team Work is in the field of Occupational Safety and Health (OSH) used quite frequently with different possible interpretations. On the one side we teach students to work in teams and on the other one also we, pedagogues, depend in the frame of teaching activities on collective effort and cooperation that lead towards the complex fully-fledged graduates who are able to solve practical tasks galore. In practice we often hear the statement - the more united you are the more powerful you are. The consequence of this statement is strongly notable exactly in the work of a safety technician. If he fails in obtaining of support from the side of his colleagues, especially from the side of management, he has only minimal chance to enforce any changes. Due to the abovementioned facts we at the Department of Technology and Information Technologies try to develop and support the team work in various aspects.

\section{Team Work between Teachers}

What is team work? It is a way of organization the work based on the common integration, mutual cooperation and responsibility of all participating team members in the process of execution of particular tasks thus leading to the fulfilment of the set goals. (Aké sú pravidlá..., 2012)

In this context we mention an interesting experience of a member of our authorial team who works as an authorised safety technician „Often I was inquired at the interviews whether I am capable of cooperation within the team. This question made me feel a bit embarrassed as I believe that I can work as a participating member in team, but the issue is whether particular company really has created suitable environment that can support the real team work. To judge whether the company really deploys the team work or it is a system of more or less cooperating individuals in the frame of an organizational structure is possible just after some months of direct experience in the company." Real team work starts within a group that shares common goals and values. All individuals of such group know each other, and thanks to this the set of their abilities creates one solid united whole. The feedback within such team plays crucial part meanwhile dynamics of the team is influenced by personal attributes of its members. The abovementioned issue is being dealt with by many specialists, for fast and brief information it is possible to use so called information shortcuts that are freely available on the Internet; for example, Krajčiová, 2012. We 
need to realize that such materials require area as it always is when we want to use shorten adequate level of knowledge from the particular forms of information sources.

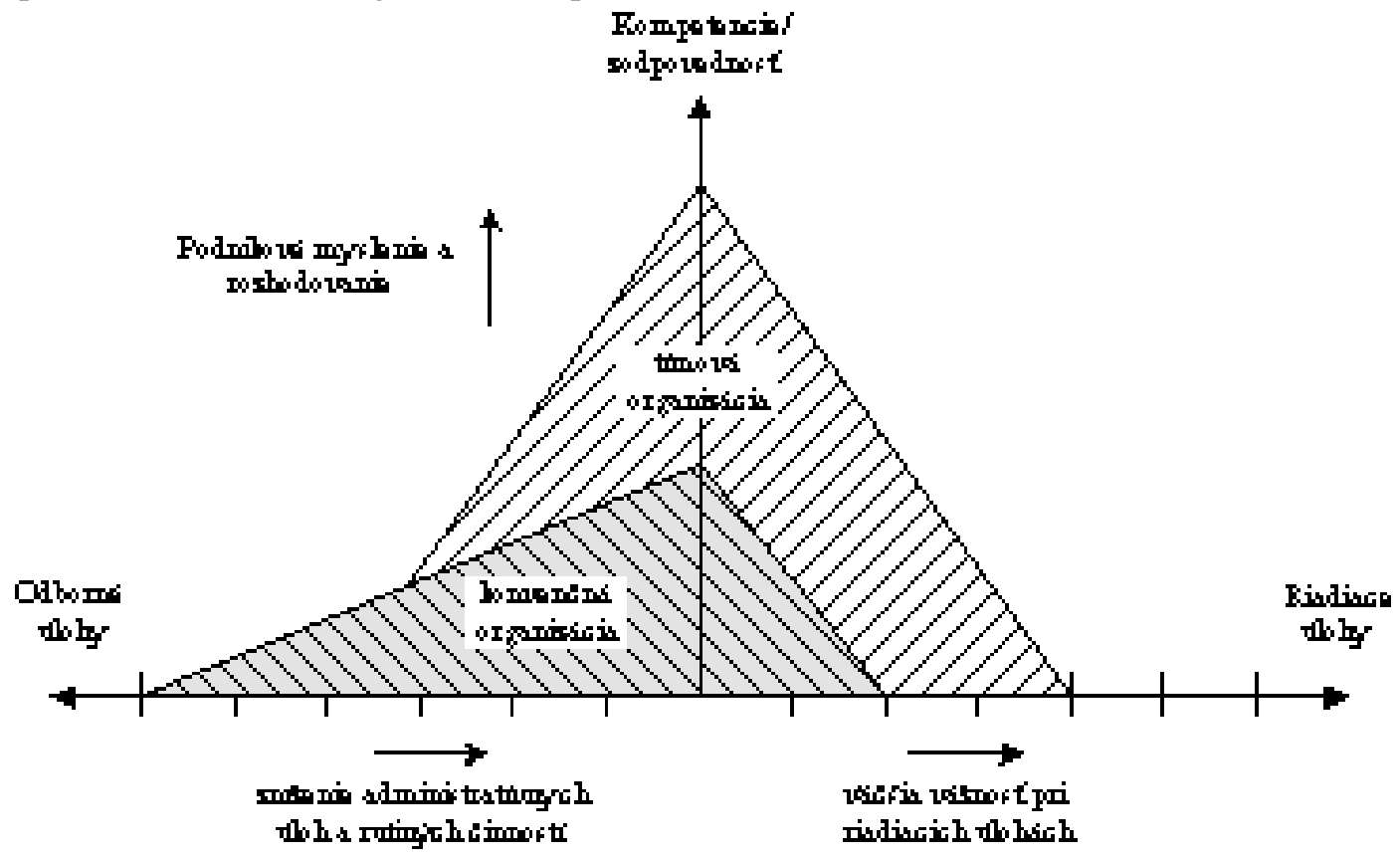

Fig.1 Difference between conventional and team organizations of work

According to Tuckman, every team faces 4 challenges in the process of completing the task: orientation, conflict, structure and outcome (forming, storming, norming and performing).(Benkovič, 2008).

Every team interacts with environments which it receives assignments from, which it passes its results to, and it itself creates its own environment. Position of a safety technician is unique from the point of view that it is integrated part of all teams.

In practice we often experience that safety technicians become members of the team only in case when it is inevitable what practically means that they have no chance to express their vocational opinion in advance and so eliminate possible risk.

Our task is to teach students about the team work. One part of our intention is to realize the team work also at the level of teachers' cooperation. If not for other reason, just to verify some presuppositions. At Department of Technology and Information Technologies we have created a team that is able to provide education for safety technicians and also to solve the issues regarding its practical support. One advantage of this team is that it has been created from fully autonomic fans and specialists in various areas who transfer their scientific outcomes into educational concepts for future safety technicians and also help the graduates from our department of the study field OSH in the process of dealing with issues that come from real practice. Huge advantage of the team lies also in the vocational experience and fullyfledged education of all particular members who may bring original and non-traditional ideas, push borders to the limit and try to initiate changes.

The aim of the team is step by step to create a functional model of education for safety technicians that will fully accept the needs of practice and will reflect the dynamics of contemporary society and in the education. In our case we deal with the cooperation among an economist, ICT specialist, linguist with the state exam in English language and authorized safety technician with a long-time practice in 4 international companies.

By means of individual work every specialist can perform in the frame of their subject and thanks to the effect of common influence we dare guarantee that students will receive demanded amount of information. The added value of the team work lies in the principle that every member is willing to cooperate and implement vocational knowledge of his colleagues into his vocational sphere. Thus; for example, an economist is 
capable of teaching curriculum that overlaps to the area of OSH. In the same time $\mathrm{i}$ tis possible to implement a set of relevant vocational vocabulary that would be prepared by both economist and linguist. Whole teaching process can be roofed by ICT - thanks to the cooperation with IT specialist.

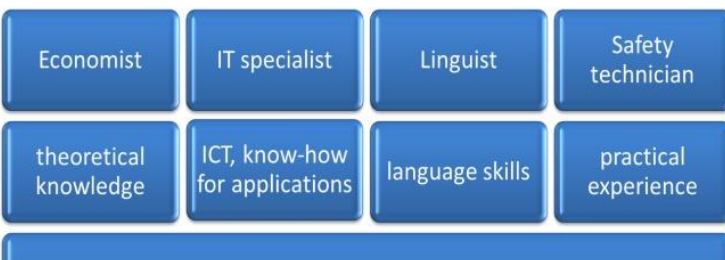

Interconnection and complementarity of experts

\section{Comprehensive knowledge base}

Fig. 2 An effect of team work

Generally, an effect of every team work is measurable by results. Satisfaction itself as a result of team work is in our case highly disputable. In practice, feeling of satisfaction is being brought through the results of our graduates, or through the expressed thankfulness for vocational consultations.

Based both on the information obtained from safety technicians in practice and on the up-todate theoretical knowledge we want to adapt the training of students in such way that we could increase chances of our graduates at the Labour Market. Our intention should be realized in the frame of more mutually connected activities in some steps.

2 Cooperation Between Informaticians and Safety Technicians in the Form of Consultation Regarding Suitable Technology.

One of the tasks of a safety technician is to record photo documentation and video records from the venues of accidents or breakdowns. To create and store documentation regarding abovementioned events is needed to have adequate digital technology.

In the process of choice of suitable digital equipment is needed to focus the attention to some selected key attributes that are immensely important for every safety technician. The first key attribute of any digital recording equipment is its ability to record whether in the form of video-sequence or a digital photograph. Nowadays, modern apparatuses are capable of both functions; for example, digital cameras can record video-sequences hand in hand with making photographs and digital still cameras can also produce and record digital video-sequence. The difference is in the quality of output. Digital cameras usually cannot create a digital picture of such quality as digital still cameras can, and vice versa, digital still cameras may face some technical restrictions (automated focusing while recording or zooming) in the process of digital recording. Still the output quality might reach the level digital camera, what logically depends on the quality and price of a digital still camera.

Based on the consultation between the informatician and safety technician we recommend in majority of cases to use a digital still camera with the function of video-recording which should be stored on the memory card in high definition 1080p.

Digital still camera should have following key attributes:

- 10-fold optical zoom (approximation of remote objects),

- Sensor definition - $10 \mathrm{Mpx}$ and more,

- Macro function (photographing details),

- Tilting and rotary display (enables taking pictures in non-standard positions and angles),

- Memory card - 8GB and more (when making high definition video).

By this example we wanted to demonstrate concrete (already executed) cooperation inside the team. This cooperation in the form of consultations has already borne fruit since we were able to design optimal documentary tool for a safety technician. We expect that the cooperation of particular team members specialists in their scientific areas, but on the other hand who are fully aware that they do not master the whole spectre of human knowledge needed for preparation of future safety technicians will become an asset for all participating sides in the educational process in the OSH area.

\section{Conclusion}

Training of future safety technicians is a matter of wide-spectrum concern. We have the ambition to create such educational environment that will enable notable improvement in students' preparation.

The most important asset of our cooperation seems to be the increment in the level of preparation of our students that should lead to their improved competitive position at the Labour Market. In accordance with demands from practice we intend to teach our students through 
creative methods supported by modern technological means. We suppose and are going to verify it in the frame of our further research that we shall be able to reach the synergic effect of educational influence on students and on wider academic environment, too.

\section{List of bibliographical sources}

[1] Aké sú pravidlá tímovej práce. dostupné: http://kariera.zoznam.sk/cl/100328/399176/Akesu-pravidla-timovej-prace 04.04.2012

[2] KRAJČIOVÁ,M.: Tímová práca - Zásady. dostupné:

http://www.krajciova.sk/MANAZER/L2_TimovaP racal_Vl.pdf 04.04.2012

[3] BENKOVIČ, P., KUIPERS, B.S.: Tímová práca - mýty a realita. E-Trend 05.06.2008. dostupné: http://podnikanie.etrend.sk/podnikanieriadenie/timova-praca-myty-a-realita.html

Doc. Ing. Vladimír Soták, CSc.

Ing. Mária Muchová

Mgr. Miroslav Šebo, PhD.

PaedDr. Róbert Soták

Katedra techniky a informačných technológií

Pedagogická fakulta

UKF v Nitre

Dražovská cesta 4

94974 Nitra

Tel: +421 376408273

E-mail: vsotak@ukf.sk, maria.muchova@ukf.sk, msebo@ukf.sk, robert.sotak@ukf.sk

Www pracovišstě: www.ktit.pf.ukf.sk 